\title{
The Newest Southerners: Generational Differences in Electoral Behavior in the Contemporary South
}

\author{
Charles Prysby \\ The University of North Carolina at Greensboro \\ prysby@uncg.edu
}

Young voters contributed disproportionately to Barack Obama's presidential victory in 2012. In fact, if the electorate had been limited to those over 30 years old, Mitt Romney might be in the White House today. Obama captured 60 percent of the vote of those under 30 , compared to 49 percent of those over 30, according to the national exit polls (Schier and BoxSteffensmeier 2013, 86). A similar pattern characterized the 2008 presidential election: Obama won 66 percent of the vote among those aged 29 or less, but under one-half of voters older than 45 (Pomper 2010, 53). The tendency for younger voters to be disproportionately Democratic emerged in the 2004 presidential election. Prior to that, Democratic presidential candidates did not consistently do better among younger voters. In 2000, for example, Al Gore did as well among older voters as he did among younger voters, and in 1992, Bill Clinton did his best among older voters, as did Walter Mondale in 1984 and Michael Dukakis in 1988 (Pomper 2001, 138; Pomper 1989, 133).

If these recent national patterns also characterize southern political behavior, there could be significant implications for the future of politics in the region. Generational replacement could slowly alter the partisan balance in the South, making it more political competitive. A region that recently appeared to be a stronghold for the GOP for both federal and state elections might become fertile ground for Democratic candidates. This study examines this possibility by analyzing generational differences in voting behavior in the South in 2012, using the 2012 American National Election Study data. The 2012 ANES survey contained an unusually large number of respondents $(\mathrm{N}=5914)$, yielding a sizable number of southern respondents $(\mathrm{N}=1906)$. Even if we restrict the analysis to voters, there still are 1300 southerners, which allows for a more thorough, detailed, and reliable analysis than is the case with any previous ANES survey.

This study addresses three research questions that seem important, each of which has some subsidiary questions:

(1) What is the nature and strength of generational differences in voting behavior in the South? Are young voters significantly more Democratic, as compared to the rest of the southern electorate? What are the political tendencies of older voters? The answers to these two questions are essential for estimating how generational replacement will alter the southern electorate.

(2) What are the sources of current generational differences in partisan preferences? In particular, how much of the difference is due to demographic differences in the composition of the generations? Are younger voters more Democratic simply because they are more likely to be a member of a minority racial or ethnic group? Do younger white voters differ from older ones in their partisan orientations? 
(3) What predictions can we make about the future of southern politics, based on the answers to the above questions? What assumptions are necessary to make these predictions, and what are the possibilities that these assumptions might prove to be incorrect?

\section{Previous Studies of Generations and Political Behavior in the South}

Several studies of southern politics published in the 1970s and the 1980s focused on generational differences in partisan attachments. Beck (1977) found that generational replacement contributed far more to the changing politics of the region than did partisan conversion of voters; younger southern voters (those born after 1945) were more likely to be independents and less likely to be Democrats, thus producing a dealignment in the South. Cassel (1977) came to similar conclusions, although she only analyzed white southerners born before 1932. On the other hand, Campbell (1977) found both generational replacement and conversion to be important sources of the changing voting behavior of white southerners. Petrocik (1987) attributed much of the decline in Democratic identification and increase in Republican identification among white southerners to changing party loyalties among older age cohorts. Analyzing data through the mid-1980s, Stanley (1988) found that shifts in party loyalty among older and younger native southern whites were comparable in magnitude, but the increasing size of the younger generation contributed more to overall change in partisan loyalties in the region. While these studies differed in their estimate of the contribution of generational replacement to the changes in southern voting patterns, all agreed that newer southern voters were less Democratic in their partisanship.

There has been far less recent research into generational differences in southern political behavior. Nadeau and Stanley (1997) analyzed the relationship between age and partisanship for native southern whites from the early 1950s through the early 1990s; they found those born after 1963 were more Republican than previous generations, although the older generations were more Republican after the mid-1980s than they were earlier. These findings reinforced those of the earlier studies discussed above. However, a more recent study (Knuckey 2010) found that younger southern whites (i.e., those under 30 years old) voted more strongly for Obama in 2008 than did those over 30, although the patterns varied by state, and even younger southern whites voted strongly for McCain in many states. These findings suggest that newer patterns of change might be emerging, with young voters contributing to Democratic, not Republican, growth, but it would unwise to conclude that without more research. The 2008 patterns might be a temporary deviation, not the start of a new trend. A more careful examination of the political attitudes and behavior of the youngest southerners is necessary in order to assess the likelihood of partisan change in the South.

Most of the existing research into generational change in the South has focused on whites or even just native southern whites. The concern of this study is with all southern voters, not just whites. To determine how generational replacement might affect southern politics, it is essential to include non-white voters in the analysis, particularly since they seem likely to be more, rather than less, important for future electoral behavior. In fact, one aim of this study is to determine how much change in southern voting patterns is likely to occur because of demographic differences across generations and how much because of change in attitudes across generations within each racial/ethnic group. 


\section{Defining Generations}

Different studies have defined generations differently. Conceptually, a generation refers to an age cohort that has similar experiences, especially in the formative political years of its members, which are generally considered to be adolescence and early adulthood (Jennings and Niemi 1981, 3-9). For example, southerners who were teenagers or young adults during the 1950s and 1960s, and therefore experienced the civil rights movement in their formative years, would be expected to have different political attitudes from those who were born later. However, it is difficult to establish precise boundaries for any particular generation. Baby boomers are typically defined as those born between 1946 and the early 1960s, for example, but the difference in the political socialization experiences of someone born in 1944 would differ little from someone born in 1946. With that in mind, the following four generations are defined as follows:

Millennials: Those 18 to 32 years of age in 2012. These individuals were born between 1980 and 1994, and they entered the electorate (i.e., turned 18) between 1998 and 2012. This definition of millennials is somewhat broader than the one most often used, which refers to those who turned 18 in this century, which began either in 2000 or 2001, depending on how one counts centuries (Howe and Strauss 2000). However, some analysts use an earlier starting date for this generation. A Pew study defined millennials as those born in 1980 or later, for example (Pew Research Center 2010). The broader definition used in this study is justified largely because those in their early 30 s are more similar in their voting behavior to younger voters than to older ones. This generation constitutes 26 percent of all southerners and 21 percent of southern voters in the 2012 ANES survey.

Generation $X$ : Those 33 to 49 years of age in 2012. These individuals were born between 1963 and 1979, and they entered the electorate between 1981 and 1997. Various age boundaries have been used in the popular media to define this generation. All agree that it follows the baby boomer generation, but some commentators define the end of the baby boomers as early as 1961, while other place it later in the 1960s (Miller 2011). The end of this generation often is defined as those born in the early 1980s, but this study establishes an earlier end, partly because those born between 1980 and 1982 are more politically similar to those born later than they are to those born earlier. This definition of generation X creates a 17-year span, which is similar in length to the age span for millennials (15 years). In the 2012 ANES survey, generation $\mathrm{X}$ accounts for 27 percent of all southerners and 28 percent of southern voters.

Boomers: Those between 50 and 66 years of age in 2012. These individuals were born between 1946 and 1962, and they entered the electorate between 1967 and 1980. ${ }^{1}$ The postWorld War II Baby Boomer generation usually is defined as those born between 1946 and the early 1960s, so this definition is consistent with most other ones, and it creates an age span for this group of 17 years, the same as that for generation X. Boomers make up 30 percent of all southerners and 32 percent of southern voters in the 2012 ANES survey.

Seniors: Those at least 67 years old in 2012. These individuals were born no later than 1945, and they entered the electorate before 1967. This is the smallest of the four generations, but even here, we have about 320 total respondents and about 250 voters, which are sufficient Ns for the analysis. This generation has a greater age span than for the other three generations, but most of the voters in this group are between 67 and 80; only about 15 percent were older than 80 in 2012. In the 2012 ANES survey, 17 percent of southerners and 19 percent of southern voters are seniors.

We should keep in mind that the definitions of the four generations are somewhat 
arbitrary and that the terms used to refer to these four generations are shorthand notations that are not precise descriptions. While accounts in the popular media may give the impression that sharp differences exist across generational boundaries, that probably is not the case. The youngest seniors are likely to be not much different from the oldest baby boomers. Similarly, the oldest millennials are unlikely to differ significantly from the very youngest members of generation $X$, regardless of what birth year is used to define the start of the millennial generation. The fact that there are no precise boundaries for the generations does not present any problems for this study. The goal here is to compare younger and older voters so that we can understand what impact generational replacement may have on southern politics, and these data are fine for that purpose.

\section{Voting Behavior and Partisanship of the Generations}

Table 1 shows the 2012 presidential vote for the four generations of southern voters defined above. Whether we look at all voters or just major-party voters, millennials were about 20 percentage points more Democratic than seniors and over 10 points more Democratic than the middle two generations. ${ }^{2}$ Millennials were more likely to vote for a minor party candidate, as we might expect, but the minor party vote was still quite small for this group. The most interesting finding in this analysis is that the millennials are the most Democratic and the seniors the least so. Since the seniors are the group of voters most likely to leave the electorate in the future, and the millennials are likely to be the most representative of those entering the electorate, the contrast between these two groups provides useful information about how southern voting patterns might change over time.

Table 1

Presidential Vote in the South by Generation, 2012

\begin{tabular}{|l|r|r|r|r|}
\hline & \multicolumn{4}{|c|}{ Generation } \\
\hline Presidential Vote & Millennials & Generation X & \multicolumn{1}{c|}{ Boomers } & \multicolumn{1}{c|}{ Seniors } \\
\hline All Voters: & & & & \\
\hline \% Obama & 60.1 & 49.4 & 49.8 & 39.8 \\
\hline \% Romney & 35.5 & 46.3 & 48.8 & 59.0 \\
\hline \% Other & 4.4 & 4.2 & 1.4 & 1.2 \\
\hline Total \% & 100.0 & 100.0 & 100.0 & 100.0 \\
\hline (N) & $(273)$ & $(356)$ & $(414)$ & $(251)$ \\
\hline Major Party Voters: & & & & 40.3 \\
\hline \% Obama & 37.2 & 51.6 & 50.5 & 59.7 \\
\hline \% Romney & 100.0 & 100.0 & 100.0 & 100.0 \\
\hline Total \% & $(261)$ & $(341)$ & $(408)$ & $(248)$ \\
\hline (N) & & & & \\
\hline
\end{tabular}

Note: See the text for the definition of the generations.

Source: 2012 American National Election Study. 
Examining presidential voting could be misleading. Possibly, the strong vote for Obama among younger voters represents the appeal of a particular candidate, not a general inclination to vote Democratic. In order to investigate this possibility, we can look at two other measures of partisanship: congressional vote and party identification. Table 2 presents the 2012 congressional vote by generation. What we find is that all generations were less likely to vote Democratic in the House elections than they were in the presidential election, but generational differences remain: millennials are about 14 percentage points more Democratic than seniors and about several points more Democratic than the middle two age groups. The generational differences for House elections are smaller than those for the presidential election, suggesting that some of the differences observed for the presidential election represent a particular appeal that Obama had to younger voters.

Table 2

Congressional Vote in the South by Generation, 2012

\begin{tabular}{|l|r|r|r|r|}
\hline & \multicolumn{4}{|c|}{ Generation } \\
\hline Congressional Vote & Millennials & Generation X & \multicolumn{1}{c|}{ Boomers } & \multicolumn{1}{c|}{ Seniors } \\
\hline \% Democrat & 47.3 & 41.7 & 44.5 & 33.6 \\
\hline \% Republican & 49.5 & 53.4 & 53.8 & 65.9 \\
\hline \% Other & 3.2 & 4.9 & 1.7 & 0.5 \\
\hline Total \% & 100.0 & 100.0 & 100.0 & 100.0 \\
\hline$(\mathrm{N})$ & $(188)$ & $(309)$ & $(357)$ & $(217)$ \\
\hline
\end{tabular}

Note: See the text for the definition of the generations.

Source: 2012 American National Election Study.

Table 3 shows the party identification for each generation of voters. To make comparisons easier, party identification has been collapsed in two different ways, each creating three categories: Democrats, independent, and Republicans. In one case, the independent leaners are included with the Democrats or Republicans; in the other case, the independent leaners are included with the pure independents. Regardless of which grouping we examine, the conclusions are similar. Millennials are substantially more Democratic than seniors (14 to 20 points more so, depending on the grouping), and they are not more likely to identify as independents, which might be a little surprising. ${ }^{3}$ Millennials also are significantly more Democratic than generation X or boomer voters; in fact, the differences here are stronger than they are for presidential or congressional voting. Thus, millennial voters in 2012 were truly more Democratic in their overall partisan orientations than the other generations, especially seniors. 
Table 3

Party Identification in the South by Generation, All Voters, 2012

\begin{tabular}{|c|c|c|c|c|}
\hline \multirow[b]{2}{*}{ Party Identification } & \multicolumn{4}{|c|}{ Generation } \\
\hline & Millennials & Generation $\mathrm{X}$ & Boomers & Seniors \\
\hline$\%$ Strong Democrat & 23.4 & 21.0 & 25.7 & 26.0 \\
\hline$\%$ Weak Democrat & 25.3 & 13.0 & 7.3 & 8.4 \\
\hline$\%$ Independent Democrat & 10.3 & 13.3 & 12.1 & 4.8 \\
\hline$\%$ Independent & 5.5 & 7.4 & 10.9 & 8.0 \\
\hline$\%$ Independent Republican & 11.7 & 10.2 & 14.0 & 16.0 \\
\hline$\%$ Weak Republican & 10.6 & 15.0 & 12.1 & 10.4 \\
\hline$\%$ Strong Republican & 13.2 & 20.1 & 17.9 & 26.4 \\
\hline Total \% & 100.0 & 100.0 & 100.0 & 100.0 \\
\hline$(\mathrm{N})$ & $(273)$ & $(353)$ & $(413)$ & $(250)$ \\
\hline \multicolumn{5}{|l|}{ Collapsed Party Identification } \\
\hline$\%$ Democrat (includ. leaners) & 59.0 & 47.3 & 45.1 & 39.2 \\
\hline$\%$ Independent & 5.5 & 7.4 & 10.9 & 8.0 \\
\hline$\%$ Republican (includ. leaners) & 35.5 & 45.3 & 44.0 & 52.8 \\
\hline Total $\%$ & 100.0 & 100.0 & 100.0 & 100.0 \\
\hline \multicolumn{5}{|l|}{ Collapsed Party Identification } \\
\hline$\%$ Democrat & 48.7 & 34.0 & 33.0 & 34.4 \\
\hline$\%$ Independent (incl. leaners) & 27.5 & 30.9 & 37.0 & 28.8 \\
\hline$\%$ Republican & 23.8 & 35.1 & 30.0 & 36.8 \\
\hline Total \% & 100.0 & 100.0 & 100.0 & 100.0 \\
\hline
\end{tabular}

Note: See the text for the definition of the generations.

Source: 2012 American National Election Study.

One more possibility needs to be considered. It might be that millennial voters in 2012 were so much more Democratic because the Obama campaign mobilized those millennials who were strongly Democratic. Perhaps if we examine all millennials, voters and nonvoters, we would find that they are not so disproportionately Democratic. To examine this possibility, we can look at the party identification of all respondents, broken down by generation, which is what Table 4 does. Among all respondents, the difference between the youngest and the oldest individuals is not as great as it is among voters: millennials are about 7-10 percentage points more Democratic than seniors, depending on the grouping of party identification. The reduction of the difference between these two groups is almost entirely due to the fact that the millennial voters are considerably more Democratic than all millennials, which suggests that one reason 
that Obama did so well among younger voters is because the Democratic mobilization effort was particularly effective in identifying young voters with Democratic inclinations and in getting them to vote.

Table 4

Party Identification in the South by Generation, All Adults, 2012

\begin{tabular}{|c|c|c|c|c|}
\hline \multirow[b]{2}{*}{ Party Identification } & \multicolumn{4}{|c|}{ Generation } \\
\hline & Millennials & Generation X & Boomers & Seniors \\
\hline$\%$ Strong Democrat & 18.6 & 19.6 & 24.3 & 22.0 \\
\hline$\%$ Weak Democrat & 19.4 & 12.5 & 8.6 & 9.4 \\
\hline$\%$ Independent Democrat & 10.5 & 13.6 & 11.9 & 7.6 \\
\hline$\%$ Independent & 15.5 & 11.7 & 13.3 & 11.0 \\
\hline$\%$ Independent Republican & 13.4 & 13.2 & 13.7 & 14.2 \\
\hline$\%$ Weak Republican & 11.1 & 13.6 & 12.4 & 9.7 \\
\hline$\%$ Strong Republican & 11.5 & 15.8 & 15.8 & 26.1 \\
\hline Total \% & 100.0 & 100.0 & 100.0 & 100.0 \\
\hline$(\mathrm{N})$ & $(485)$ & $(514)$ & $(571)$ & $(318)$ \\
\hline \multicolumn{5}{|l|}{ Collapsed Party Identification } \\
\hline$\%$ Democrat (includ. leaners) & 48.5 & 45.7 & 44.8 & 39.0 \\
\hline$\%$ Independent & 15.5 & 11.7 & 13.3 & 11.0 \\
\hline$\%$ Republican (includ. leaners) & 36.0 & 42.6 & 41.9 & 50.0 \\
\hline Total $\%$ & 100.0 & 100.0 & 100.0 & 100.0 \\
\hline \multicolumn{5}{|l|}{ Collapsed Party Identification } \\
\hline$\%$ Democrat & 38.0 & 32.1 & 32.9 & 31.4 \\
\hline$\%$ Independ. (includ. leaners) & 39.4 & 38.5 & 38.9 & 32.8 \\
\hline$\%$ Republican & 22.6 & 29.4 & 28.2 & 35.8 \\
\hline Total $\%$ & 100.0 & 100.0 & 100.0 & 100.0 \\
\hline
\end{tabular}

Note: See the text for the definition of the generations.

Source: 2012 American National Election Study. 
Still, even if we look at all millennials, they are more Democratic than the other generations, especially seniors. Furthermore, if we examine another measure of feelings toward the parties, we find substantial differences between millennials and seniors, and we find only small differences between millennial voters and all millennials. Table 5 shows the mean scores toward the two major parties on the feeling thermometer by generation. ${ }^{4}$ Millennials are substantially warmer toward Democrats and cooler toward Republicans than any of the other generations, and seniors are just the opposite. Moreover, the difference between all millennials and those who voted in 2012 is modest: young voters were 15 degrees warmer toward the Democrats, while all young adults were 13 points warmer. Even if Democrats are less effective in mobilizing young Democratic voters in 2016, or if Republicans are more effective in mobilizing their young supporters, younger southern voters should be disproportionately Democratic in their voting, and not just in the presidential election. Furthermore, seniors should continue to be the most Republican, and this generation will be a declining share of the electorate as time marches on.

Table 5

Feelings Toward the Parties in the South by Generation, 2012

\begin{tabular}{|l|r|r|r|r|}
\hline \multirow{2}{*}{$\begin{array}{l}\text { Mean Scores on the Feeling } \\
\text { Thermometer Toward: }\end{array}$} & \multicolumn{4}{|c|}{ Generation } \\
\cline { 2 - 5 } & Millennials & Generation X & Boomers & Seniors \\
\hline All Voters: & & & & \\
\hline Democratic Party & 57.6 & 51.6 & 49.2 & 46.9 \\
\hline Republican Party & 42.5 & 45.4 & 48.3 & 53.8 \\
\hline Difference in scores & 15.1 & 6.2 & 0.9 & -7.1 \\
\hline All Adults & & & & 47.4 \\
\hline Democratic Party & 55.2 & 52.6 & 49.9 & 52.9 \\
\hline Republican Party & 42.7 & 45.1 & 48.0 & -5.5 \\
\hline Difference in scores & 12.6 & 7.3 & 1.9 & \\
\hline
\end{tabular}

Note: See the text for the definition of the generations.

Source: 2012 American National Election Study.

The fact that seniors are the most Republican generation seems to contradict earlier research into generational differences in southern politics. As was pointed out above, several studies in the 1970s and 1980s found that seniors were more Democratic than baby boomers. One explanation for the difference in the findings of earlier research and this study probably is the increasing tendency for southerners to bring their party identification into alignment with the ideological orientation (Knuckey 2001; 2006). In the 1970s, older white voters, even those in their 40s or 50s, may have retained their strong Democratic identification, which was established during the Solid South era, even though they were more conservative than baby boomers, and even though they may have voted for Republican presidential candidates. By 2012, these older voters, all of whom would now be seniors, were likely to have brought their 
party identification in line with their ideological orientation. Additionally, most voters who were seniors in the 1970s and 1980s were born before most of those who were seniors in 2012, which means that the 2012 seniors had different life experiences on the whole. For example, over onehalf of the 2012 seniors were born after 1939, which meant that they entered the electorate after 1960 , and thus were adolescents or young adults during the civil rights era.

\section{Sources of Differences in Voting Patterns Across Generations}

The differences between the generations that are present in Tables 1-5 could be a result of racial and ethnic differences. MacManus (2012, 56-62) describes how these demographic patterns are changing in the South, changes that have the potential to alter politics in the region. Table 6 shows that there are substantial differences between the generations in their racial and ethnic composition. Almost three-fourth of seniors are white, but only about one-half of millennials are, with the other two generations about halfway between these two figures. Blacks, Hispanics, and Asian-Americans are all more Democratic than whites, both in the South and in the North, so these racial and ethnic differences could be the reason why millennials are the most Democratic generation and seniors the least so.

Table 6

Race by Generation for Southern Voters, 2012

\begin{tabular}{|l|r|r|r|r|}
\hline & \multicolumn{4}{|c|}{ Generation } \\
\hline Race or ethnicity & Millennials & Generation X & \multicolumn{1}{|c|}{ Boomers } & \multicolumn{1}{|c|}{ Seniors } \\
\hline \% White, not Hispanic & 51.1 & 60.8 & 65.9 & 73.6 \\
\hline \% Black & 31.0 & 20.0 & 23.2 & 12.8 \\
\hline \% Hispanic & 13.5 & 15.2 & 7.0 & 10.0 \\
\hline \% Other & 4.4 & 3.9 & 3.9 & 3.6 \\
\hline Total \% & 100.0 & 100.0 & 100.0 & 100.0 \\
\hline (N) & $(273)$ & $(355)$ & $(413)$ & $(250)$ \\
\hline
\end{tabular}

Note: See the text for the definition of the generations.

Source: 2012 American National Election Study.

To determine the extent to which these racial and ethnic differences are responsible for the political differences between the generations, we can look at the voting patterns of each generation with race or ethnicity held constant. Table 7 has these data, and they show that significant differences remain across generations even within most racial/ethnic groups. Among whites, millennials were about 12 points more Democratic than seniors in their 2012 presidential vote. A similar generational difference is present among Hispanics. No such pattern exists among blacks, who were highly likely to vote for Obama regardless of their age. Strong differences exist between millennials and seniors in the Asian and other category, but the Ns are so small that no reliable conclusions can be drawn from these figures. As we can see from the top row of Table 7, among all voters, millennials were over 20 points more for Obama than seniors. Comparing this difference against the generational differences among whites, we can 
estimate that roughly one-half of the total difference between millennials and seniors is a result of the difference in racial and ethnic composition, and the other half is due to the tendency for younger whites, Hispanics, and perhaps other minorities (excluding blacks) to be more Democratic in their voting than older individuals of the same race or ethnicity.

Table 7

Presidential Vote by Race and Generation in the South, 2012

\begin{tabular}{|l|r|r|r|r|}
\hline \multirow{2}{*}{$\begin{array}{l}\text { Percent of two-party vote for } \\
\text { Obama }\end{array}$} & \multicolumn{4}{|c|}{ Generation } \\
\cline { 2 - 5 } & Millennials & Generation X & \multicolumn{1}{|c|}{ Boomers } & Seniors \\
\hline All major-party voters & $63 \%$ & $52 \%$ & $51 \%$ & $40 \%$ \\
& $(261)$ & $(341)$ & $(408)$ & $(248)$ \\
\hline White, non-Hispanic voters & $37 \%$ & $34 \%$ & $31 \%$ & $25 \%$ \\
& $(134)$ & $(207)$ & $(266)$ & $(182)$ \\
\hline Black voters & $93 \%$ & $100 \%$ & $95 \%$ & $100 \%$ \\
& $(80)$ & $(69)$ & $(96)$ & $(32)$ \\
\hline Hispanic voters & $81 \%$ & $60 \%$ & $66 \%$ & $68 \%$ \\
& $(36)$ & $(52)$ & $(29)$ & $(25)$ \\
\hline Asian and other voters & $100 \%$ & $50 \%$ & $75 \%$ & $57 \%$ \\
& $(11)$ & $(12)$ & $(16)$ & $(7)$ \\
\hline
\end{tabular}

Note: Figures are the percent of the two-party vote for Obama, with the Ns that the percentages are based on in parentheses. See the text for the definition of the generations.

Source: 2012 American National Election Study.

There are other demographic differences between the generations, many of which reflect life cycle forces. For example, millennials are more likely to be students, to be unemployed, or to be unmarried. Seniors, not surprisingly, are more likely to be retired and to be married or widowed. These life cycle characteristics of millennials will change as they age, but that does not mean that millennials will become more Republican as they age. Most research has shown that while that while the intensity of partisanship is stronger among older voters, there is little tendency for individuals to shift the direction of their party identification as a result of life cycle forces (Abramson 1979; Lewis-Beck et al. 2008; Miller and Shanks 1996). One possible exception might be the effect of change in marital status, which has recently emerged as a significant influence on voting behavior (Ray 2008). Republicans now do better among married voters, so perhaps as the proportion of millennials who are married increases (only 35 percent are married, although another 17 percent have a partner), there could be some movement toward the GOP.

One important demographic characteristic cannot be examined with these data: where the individual grew up. It could be that the greater inclination of younger southerners to vote for Democrats is a result of there being a disproportionate number of young southerners who grew up in the North. Hood and McKee (2010) found that factor to be an important explanation for the support that Obama received in North Carolina in 2008. Unfortunately, while the 2012 ANES survey asked respondents where they grew up, that variable is not included in the most recent release (April, 2014). Until this demographic variable is included in a later release, we 
can only speculate on its possible effect.

Having established that younger voters are more likely to vote for Democrats, even when race and ethnicity is taken into account, we now can analyze the attitudes that are behind this behavior. Since blacks are so heavily Democratic, it is better to exclude them from this analysis, as including them might confound the relationships that exist among non-blacks. Table 8 shows the attitudes of the four generations on a number of issues. On economic issues, millennials stand out as the most liberal group in each case, being considerably more liberal than even those in the next oldest generation. Seniors are overall the most conservative generation on economic issues, and the other two generations fall between the oldest and youngest generations in their economic attitudes.

\section{Table 8}

Issue Orientations in the South by Generation, 2012

\begin{tabular}{|c|c|c|c|c|}
\hline \multirow[b]{2}{*}{ Issue Orientation } & \multicolumn{4}{|c|}{ Generation } \\
\hline & Millennials & Generation X & Boomers & Seniors \\
\hline \multicolumn{5}{|l|}{ ECONOMIC ISSUES: } \\
\hline $\begin{array}{l}\% \text { favoring more government } \\
\text { services and spending }\end{array}$ & 28.2 & 23.7 & 21.8 & 17.1 \\
\hline $\begin{array}{l}\% \text { in favor of the ACA } \\
\text { (Obamacare) }\end{array}$ & 39.6 & 27.8 & 33.4 & 29.5 \\
\hline $\begin{array}{l}\% \text { favoring government action to } \\
\text { reduce inequality }\end{array}$ & 32.1 & 18.2 & 19.8 & 13.6 \\
\hline $\begin{array}{l}\% \text { favoring more environmental } \\
\text { regulation }\end{array}$ & 57.7 & 51.9 & 52.8 & 33.2 \\
\hline \multicolumn{5}{|l|}{ SOCIAL ISSUES: } \\
\hline $\begin{array}{l}\% \text { believing that abortion should } \\
\text { always be allowed }\end{array}$ & 44.7 & 47.5 & 43.0 & 31.3 \\
\hline $\begin{array}{l}\% \text { believing that gay marriage } \\
\text { should be allowed }\end{array}$ & 49.2 & 41.3 & 24.5 & 21.0 \\
\hline \multicolumn{5}{|l|}{ RACIAL ISSUES: } \\
\hline $\begin{array}{l}\% \text { favoring govt. action for fair } \\
\text { job treatment for blacks }\end{array}$ & 34.9 & 32.2 & 28.1 & 31.8 \\
\hline $\begin{array}{l}\% \text { high on the support for blacks } \\
\text { index }\end{array}$ & 36.7 & 23.9 & 20.2 & 21.6 \\
\hline
\end{tabular}

Note: Blacks and nonvoters are excluded from the analysis. See the text for the definition of the generations and for details on the variables.

Source: 2012 American National Election Study. 
For the two social issues examined, abortion and gay marriage, millennials are significantly more liberal than seniors, although millennials do not differ much from boomers and members of generation $\mathrm{X}$ when it comes to abortion. The more liberal attitudes of millennials on abortion and gay marriage reflect the fact that millennials are much less religious. Over one-third of millennials report that they are not religious, compared to only one-fourth of generation Xers and even small proportions for seniors. Only 27 percent of millennials are regular church attenders, compared to 44 percent of seniors. Millennials also are more likely to say that the Bible is the word of man, not God.

Millennials also are quite different from the other three generations on racial issues. One of the variables in the table is an index of attitudes toward blacks, which is formed from three questions about blacks; this index measures how favorable or unfavorable the respondent views blacks. ${ }^{5}$ Similar measures have been used by other researchers, who often term this racial resentment (Aistrup, Kisangani, and Piri 2010; Knuckey 2005; 2011). The other racial issue variable is a question about whether the federal government should take action to ensure that blacks receive fair treatment when it comes to jobs; this variable is a measure of government policy toward blacks. Interestingly, the three older generations do not differ much in their attitudes on racial issues. Seniors are not significantly less favorable toward blacks than others, contrary to what some might expect. Millennials stand out as more favorable toward blacks on these questions and distinct from all three other generations.

These differences in issue orientations and attitudes could be why millennials are more Democratic in their voting. To determine if this is indeed the case, we can look at logistic regressions of the 2012 presidential vote. Three different regression models are shown in Table 9. Model 1 predicts the vote using just party identification, ideological self-identification, and three attitudinal indices, one each for social welfare issues, moral issues, and feelings toward blacks. ${ }^{6}$ Because blacks voted overwhelmingly for Obama, they are excluded from this analysis, since there is little voting behavior to explain. This simple model predicts the vote rather well. We then can add in dummy variables for generations, which will tell us whether a voter's generation is related to voting once party identification, ideology, and the three other attitudes are considered. ${ }^{7}$ Model 2 shows us that adding generation to the equation does not add any explanatory power to the analysis. The coefficient for each dummy variable (millennials, generation $\mathrm{X}$, and boomers) is weak and statistically insignificant, and there is no increase in either the psuedo $\mathrm{R}^{2}$ or the percentage of cases predicted over Model 1. Finally, Model 3 includes several short-term attitudes in the equation: evaluations of Obama's economic and foreign policy performance and assessments of the character traits of the candidates. ${ }^{8}$ The more complete model does improve our predictive ability, measured either by the psuedo $\mathrm{R}^{2}$ or the percentage of cases predicted, but the dummy variables for the generations again have weak and statistically insignificant coefficients. The coefficients for party identification and for attitudes toward blacks are much lower in Model 3 than in the other two models, which indicates that these two orientations strongly influence evaluations of Obama, which in turn affect the vote. The conclusion that we should draw from this analysis is that millennials are more Democratic because of their party identification and their liberal attitudes on the issues identified here. 
Table 9

Logistic Regression of the Presidential Vote in the South, 2012

\begin{tabular}{|c|c|c|c|}
\hline \multirow[b]{2}{*}{ Independent Variables } & \multicolumn{3}{|c|}{ Regression Model } \\
\hline & Model 1 & Model 2 & Model 3 \\
\hline Party identification & $\begin{array}{l}1.097 * * \\
(.096)\end{array}$ & $\begin{array}{l}1.103 * * \\
(.097)\end{array}$ & $\begin{array}{l}.668^{* *} \\
(.140)\end{array}$ \\
\hline Ideological identification & $\begin{array}{l}.082 \\
(.130)\end{array}$ & $\begin{array}{l}.066 \\
(.133)\end{array}$ & $\begin{array}{l}-.530 \\
(.209)\end{array}$ \\
\hline Social welfare index & $\begin{array}{l}.675^{* *} \\
(.129)\end{array}$ & $\begin{array}{l}.671 * * \\
(.131)\end{array}$ & $\begin{array}{l}.496 * * \\
(.188)\end{array}$ \\
\hline Moral issues index & $\begin{array}{l}.788^{* * *} \\
(.161)\end{array}$ & $\begin{array}{l}.783 * * \\
(.163)\end{array}$ & $\begin{array}{l}.759 * * \\
(.244)\end{array}$ \\
\hline Index of attitudes toward blacks & $\begin{array}{l}.407 * * \\
(.105)\end{array}$ & $\begin{array}{l}.410 * * \\
(.108)\end{array}$ & $\begin{array}{l}.111 \\
(.162)\end{array}$ \\
\hline Obama's economic performance & & & $\begin{array}{l}.809^{* *} \\
(.236)\end{array}$ \\
\hline Obama's foreign policy performance & & & $\begin{array}{l}.400 * \\
(.205)\end{array}$ \\
\hline Candidate character trait index & & & $\begin{array}{l}1.077 * * \\
(.219)\end{array}$ \\
\hline Millennials & & $\begin{array}{l}.141 \\
(.436)\end{array}$ & $\begin{array}{l}-.505 \\
(.649)\end{array}$ \\
\hline Generation X & & $\begin{array}{l}.219 \\
.(401)\end{array}$ & $\begin{array}{l}-.041 \\
(.600)\end{array}$ \\
\hline Boomers & & $\begin{array}{l}.066 \\
(.356)\end{array}$ & $\begin{array}{l}-.004 \\
(.584)\end{array}$ \\
\hline$(\mathrm{N})$ & $(928)$ & $(928)$ & $(885)$ \\
\hline Nagelkerke $\mathrm{R}^{2}$ & .811 & .811 & .909 \\
\hline$\%$ of cases correctly predicted & 92.0 & 91.6 & 95.5 \\
\hline
\end{tabular}

$* * \mathbf{p}<.01, * \mathbf{p}<.05$ (one-tailed tests)

Note: Figures are logistic regression coefficients, with standard errors in parentheses. Blacks are excluded from the analysis. Seniors are the generation that the other generations are compared to. See the text for the definition of the generations and for details on the independent variables.

Source: 2012 American National Election Study.

The above analysis assumes that the independent variables have similar effects across the generations, but it is possible that younger voters are more strongly influenced by some variables, while older voters are more affected by other factors. One hypothesis is that the presidential vote of younger voters will be affected less by long-term political dispositions, such as party identification or ideological orientation, and more by short-term attitudes toward the candidates and current issues, at least in comparison to the voting behavior of older voters. Older voters are more likely to have deeply held partisan and ideological dispositions, which will make them less influenced by short-term forces. This possibility is examined by running separate logistic regressions for each generation, using the complete model of the vote discussed above (Model 3). The analysis results are reported in Table 10. To simplify the comparison, the two middle generations have been combined. 
Table 10

Logistic Regression of the Presidential Vote in the South by Generation, 2012

\begin{tabular}{|c|c|c|c|}
\hline & \multicolumn{3}{|c|}{ Generation } \\
\hline Independent Variables & Millennials & $\begin{array}{l}\text { Generation X } \\
\text { and Boomers }\end{array}$ & Seniors \\
\hline Party identification & $\begin{array}{l}-.314 \\
(.486)\end{array}$ & $\begin{array}{l}1.012 * * \\
(.204)\end{array}$ & $\begin{array}{l}1.273^{*} \\
(.654)\end{array}$ \\
\hline Ideological identification & $\begin{array}{l}.335 \\
(.660)\end{array}$ & $\begin{array}{l}-.872 \\
(.292)\end{array}$ & $\begin{array}{l}-1.613 \\
(1.133)\end{array}$ \\
\hline Social welfare index & $\begin{array}{l}2.128 * \\
(1.040)\end{array}$ & $\begin{array}{l}.200 \\
(.237)\end{array}$ & $\begin{array}{l}1.509 \\
(1.419)\end{array}$ \\
\hline Moral issues index & $\begin{array}{l}1.236 \\
(.859)\end{array}$ & $\begin{array}{l}.510^{*} \\
(.294)\end{array}$ & $\begin{array}{l}3.348 * * \\
(1.304)\end{array}$ \\
\hline Index of attitudes toward blacks & $\begin{array}{l}-.871 \\
(.655)\end{array}$ & $\begin{array}{l}.247 \\
(.201)\end{array}$ & $\begin{array}{l}1.086 \\
(.794)\end{array}$ \\
\hline Obama's economic performance & $\begin{array}{l}2.400 * * \\
(.986)\end{array}$ & $\begin{array}{l}.435 \\
(.290)\end{array}$ & $\begin{array}{l}-.914 \\
(1.837)\end{array}$ \\
\hline Obama's foreign policy performance & $\begin{array}{l}.573 \\
(.957)\end{array}$ & $\begin{array}{l}.593 * \\
(.256)\end{array}$ & $\begin{array}{l}.978 \\
(1.228)\end{array}$ \\
\hline Candidate character trait index & $\begin{array}{l}2.528^{*} \\
(1.292)\end{array}$ & $\begin{array}{l}1.023^{* *} \\
(.263)\end{array}$ & $\begin{array}{l}3.435^{*} \\
(1.940)\end{array}$ \\
\hline$(\mathrm{N})$ & $(191)$ & $(527)$ & $(194)$ \\
\hline Nagelkerke $\mathrm{R}^{2}$ & .952 & .900 & .967 \\
\hline$\%$ of cases correctly predicted & 97.4 & 95.9 & 99.0 \\
\hline
\end{tabular}

$* * \mathbf{p}<.01, * \mathbf{p}<.05$ (one-tailed tests)

Note: Figures are logistic regression coefficients, with standard errors in parentheses. Blacks are excluded from the analysis. See the text for the definition of the generations and for details on the independent variables.

Source: 2012 American National Election Study.

There are differences across the generations in the effect of various variables on the vote, although the interpretation of the results is complicated by the fact that for the seniors there are a number of variables that have large coefficients but large standard errors. With this caveat in mind, some conclusions seem clear. First, the presidential vote of millennials in 2012 is not related to party identification, once other variables are included in the equation, which is consistent with the hypothesis discussed above. In contrast, the other generations were strongly influenced by their party identification, even with all of the other variables included in the analysis. Second, millennials were more strongly affected by their assessments of the character traits of the candidates than were the two middle generations, although the comparison with seniors is ambiguous: the coefficient for the trait index is larger for seniors, but it has a large standard error, so the confidence interval for the coefficient is wide. Third, seniors were affected 
by their attitudes on moral issues much more than were younger voters. Fourth, millennials were more responsive to economic concerns, including both evaluations of Obama's economic performance and attitudes toward social welfare issues, than were the older generations.

While millennials do seem to have been more strongly affected by short-term attitudes, particularly assessments of the character traits of the candidates and evaluations of Obama's handling of the economy, we should keep in mind that these short-term attitudes are shaped by more stable political orientations, such as party identification and ideological orientations. One important reason why younger voters had more positive evaluations of Obama's performance and more favorable assessments of his character traits, relative to Romney's, was because younger voters are more liberal and more Democratic. Nevertheless, these results suggest that younger voters may be more volatile in their voting behavior than older voters. Shifts in shortterm forces that are strongly favorable to Republicans could reduce the Democratic advantage among younger voters in future elections more than would be true for older voters.

\section{Implications for the Future}

The findings of this study show that millennials are the most Democratic generation and seniors the least so. It is not just that millennials voted disproportionately for Obama in 2012. These younger voters also display stronger attachments to the Democratic Party in general, and they are not more likely to be independent in their party identification, contrary to what some might expect. Seniors, who constitute the most Republican generation, are certain to be departing the electorate at a much greater rate than the younger generations. Their departure will disproportionately deplete the ranks of Republican voters. Therefore, Democrats will gain electoral strength as generational replacement unfolds provided that two assumptions hold true: (1) the other generations remain about as Democratic as they currently are; and (2) the postmillennial generation resembles millennials.

There are possible reasons why the above two assumptions might not hold true. First of all, the generations examined in this study could become more Republican in the future through: (a) the conversion of existing voters so that they are more Republican or less Democratic than they are now; (b) the net addition of Republican voters to these generations through migration into the South from the North or from outside the country; or (c) the net addition of Republicans to these generations from current nonvoters becoming voters in the future. Another way for Republicans to compensate for the loss of seniors would be by attracting a higher percentage of the post-millennial generation voters.

What is the likelihood of each of these possibilities? Probably the best hope for Republicans is that period effects - developments that have significant lasting effects on the party identification of voters - alter the partisan landscape in a Republican direction. Such effects could be produced by some combination of important political events, the success or failure of presidential administrations, and the behavior of the parties and their leaders. These effects probably would disproportionately influence millennial voters, as many of them are still forming their basic political orientations. If Obama ends his second term with a low approval rating, for example, that not only would benefit Republican candidates in 2016, but also might help shift more lasting partisan orientations toward the GOP. If an unsuccessful Obama administration were followed by a successful GOP presidency, the likelihood of shifts in partisan orientations would increase. Of course, future political developments might benefit Democrats, not Republicans. We can only speculate on the possible scenarios that might unfold, but there have been enough examples in recent decades to demonstrate that predictions about 
the future of American politics often fail to materialize because of unpredicted developments.

Apart from period effects, Republican hopes for the conversion of existing voters seem more problematic. One group that the GOP might do better among is the boomer generation. In presidential and congressional voting in 2012, boomers were very similar to members of generation $\mathrm{X}$, but they are more conservative on racial and social issues (although not on economic issues), and they have more favorable attitudes toward the Republican Party, as measured by feeling thermometer scores. Some of these more conservative boomers who nevertheless voted Democratic could be converted to Republican voters, especially on the basis of racial resentment. As minorities become a greater part of the Democratic coalition, some older whites might react by becoming more Republican.

Republican conversion of existing millennial voters seems less likely, absent strong period effects, given that these voters hold relatively more liberal attitudes on economic, social, and racial issues. Party identification and ideology are more closely related now than in the past, and they seem likely to remain strongly related, so it will be more difficult for Republicans to gain support among those who are ideologically closer to the Democratic Party. Furthermore, life cycle effects on the direction of party identification are generally considered to be weak, so there is little reason to think that these younger voters will naturally become more Republican as they age, although changes in marital status could shift the millennials a bit toward the GOP, as discussed earlier.

Could Republicans gain through the mobilization of nonvoters? This study shows that young nonvoters were less Democratic than young voters, suggesting that Democrats did a better job than Republicans in getting their young supporters to the polls. The turnout of young voters will increase as they get older, and an improved Republican effort to mobilize them would at least slightly reduce the Democratic advantage among millennials, although they still would be the most pro-Democratic generation. Republican gains through the mobilization of generation $\mathrm{X}$ or boomer nonvoters seem more problematic, largely because it is more difficult to change the voting habits of older individuals, but small gains might be possible. Also, Republicans might make small gains by making it more difficult for Democrats to mobilize their voters through voter suppression measures, such as those that have already been enacted in several southern states.

Republicans potentially could compensate for the loss of senior voters through migration patterns. In the past, migration from the North helped the GOP, and perhaps it could again. Northern migrants to the South, either those coming for an employment opportunity or to retire, tend to be whites who are above average in income, and southern Republicans tend to do well among upper-income whites, so these new migrants could contribute to Republican electoral success. However, future migrants from the North may be less Republican than has been the case in the past. There is some evidence that the most recent northern migrants have been disproportionately Democratic, despite their high income levels, especially in states such as Virginia and North Carolina (MacManus 2012). The growing success of Democrats in northern Virginia and in the Raleigh-Durham area of North Carolina attests to this trend (Hood and McKee 2010). The Democratic appeal to these new southerners presumably is because they are well-educated professionals who are liberal on many issues; also, there may be a sizable number of blacks and other minorities in this group. Unfortunately, the 2012 ANES data do not allow us to identify recent migrants to the South, so this study cannot investigate this question. While more research is needed to develop a definitive description of the political character of the most recent northern migrants to the region, and research surely is necessary to determine what the 
future migrants will be like, Republicans in many southern states may find new migrants to be less inclined to support the GOP. Migration from outside the country is an even less likely source of help for the GOP. First of all, most of those coming to the South from other countries will not be citizens, preventing them from being voters, at least until they attain citizenship. Second, most are likely to come from Latin America, and Latinos have been strongly Democratic in recent elections. Even if Republicans improve their appeal to Latino voters by modifying their policies on immigration issues, Democrats are likely to retain an advantage with this group of voters.

Finally, Republicans could compensate for the loss of older Republicans by attracting a large number of voters who enter the electorate in 2016 or later, which we can label the postmillennial generation. In some ways this seems like the least likely way that Republicans could compensate for the decline in the number of senior voters. First of all, the post-millennial generation is projected to have a higher percentage of minorities than the millennial generation; unless Republican are able to drastically improve their appeal to Latino voters, this will work to the advantage of the Democrats. Second, millennials are disproportionately Democratic because they are more liberal than the older generations, and there is little reason to think that the postmillennial voters will be more conservative in their political attitudes than the millennials. However, this conclusion should be qualified by recognizing that post-millennials will be particularly influenced by the events and life experiences that take place during their formative years.

Exit polls from the 2014 midterm congressional elections show the continuation of generational differences, despite the widespread success of Republicans in the South. ${ }^{9}$ In Arkansas, North Carolina, and Virginia, the Democratic candidates for the U.S. Senate ran about 10 to 12 percentage points better among major-party voters under 30 than they did among those 65 and older. Differences were even greater in some states: a 14 point Democratic advantage in Louisiana, a 17 point advantage in Georgia, and a whopping 23 point advantage in Texas (even though a majority of younger voters cast a ballot for the Republican candidate, John Cornyn). Overall, these generational differences were a bit smaller than in the 2012 presidential vote, where there was a 20 point difference between seniors and millennials, but they are quite comparable to the 2012 congressional vote patterns, where there was a 14 point difference. Furthermore, there were three Senate races where the Democratic candidate was the same in both 2008 and 2012 and where there was a contested election in both years, and the difference in support for Democrats between millennials and seniors in 2014 was similar to the difference in 2008. ${ }^{1}$ In all three cases (Louisiana, North Carolina, and Virginia), the Democratic candidate did worse across all age groups in 2014 than in 2008, going down to defeat in Louisiana and North Carolina and narrowly winning in Virginia, but the difference between younger and older voters remained. It will be interesting to see if these generational differences persist in 2016.

\section{Conclusion}

The findings of this study suggest that Democrats are likely to gain electoral support, albeit slowly and unevenly, as a result of generational replacement. Seniors, who are the most Republican generation, will be departing the electorate over the next few decades. Millennials are the most Democratic generation, partly because more of them are non-white and partly because younger whites are more liberal. These factors suggest that post-millennials, who are just beginning to enter the electorate, are likely to be similar to millennials in their voting behavior. Democrats should therefore gain as millennials and post-millennials become a greater 
share of the southern electorate.

Republicans could maintain their current electoral strength by compensating for the loss of senior voters through net gains from the conversion of existing voters, from migration to the region, from greater mobilization of Republican nonvoters, and from winning the vote of the next generation. None of these possibilities appears to be a likely source of significant Republican gains, but they should be monitored to verify that assumption. We should also recognize that how the process of generational replacement plays out will undoubtedly vary across the states, for all of the reasons suggested above. Furthermore, any assessment of the future of southern electoral politics also must take into account the possible impact of important period effects, which are difficult to predict, but cannot be dismissed as irrelevant. Moreover, the outcome of any particular election may deviate substantially from the long-term trends because of short-term forces. Thus, Republicans may do extremely well in a number of future elections, even if their long-term prospects are slowly eroding, as the 2014 election results illustrate. While the direction of change in southern politics may be changing, there is sufficient uncertainty to make the future study of southern politics interesting and worthwhile. 


\section{Bibliography}

Abramson, Paul R. 1979. "Developing Party Identification: A Further Examination of LifeCycle, Generational and Period Effects." American Journal of Political Science 23: 78-96.

Aistrup, Joseph A., Emizet F. Kisangani, and Roxanne L. Piri. 2010. "The Legacy of Race in 2008." In Presidential Elections in the South: Putting 2008 in Political Context, ed. Branwell DuBose Kapeluck, Robert P. Steed, and Laurence W. Moreland. Boulder, CO: Lynne Reinner.

Beck, Paul Allen. 1977. "Partisan Dealignment in the Postwar South.” American Political Science Review 71: 477-498.

Campbell, Bruce A. 1977. "Patterns of Change in the Partisan Loyalties of Native Southerners: 1952-1972." The Journal of Politics 39: 730-761.

Cassel, Carol A. 1977. "Cohort Analysis of Party Identification Among Southern Whites, 1952-1972." Public Opinion Quarterly 41: 28-33.

Holian, David B., and Charles Prysby. 2014. "Candidate Character Traits in the 2012 Presidential Election." Presidential Studies Quarterly 44:484-505.

Hood, M. V. III, and Seth C. McKee. 2010. "What Made Carolina Blue? In-Migration and the 2008 North Carolina Presidential Vote." American Politics Research 38: 266-302.

Howe, Neil, and William Strauss. 2000. Millennials Rising: The Next Great Generation. New York, NY: Vintage.

Jennings, M. Kent, and Richard G. Niemi. 1981. Generations and Politics. Princeton, NJ: Princeton University Press.

Knuckey, Jonathan. 2001. "Ideological Realignment and Partisan Change in the American South, 1972-1996." Politics and Policy 29: 337-358.

Knuckey, Jonathan. 2005. "Racial Resentment and the Changing Partisanship of Southern Whites." Party Politics 11: 5-28.

Knuckey, Jonathan. 2006. "Explaining Recent Changes in the Partisan Identifications of Southerners." Political Research Quarterly 59: 57-70.

Knuckey, Jonathan. 2010. "Generational Changes.” In Presidential Elections in the South: Putting 2008 in Political Context, ed. Branwell DuBose Kapeluck, Robert P. Steed, and Laurence W. Moreland. Boulder, CO: Lynne Reinner.

Knuckey, Jonathan. 2011. "Racial Resentment and Vote Choice in the 2008 U.S. Presidential Election." Politics \& Policy 39: 559-582.

Lewis-Beck, Michael S., William G. Jacoby, Helmut Norpoth, and Herbert F. Weisberg. 2008. The American Voter Revisited. Ann Arbor, MI: University of Michigan Press.

MacManus, Susan A. 2012. “The South's Changing Demographics.” In The Oxford Handbook of Southern Politics, ed. Charles S. Bullock III and Mark Rozell. New York: Oxford University Press.

Miller, Jon. 2011. "The Generation X Report.” Research Report from the Longitudinal Study of American Youth. University of Michigan Institute of Social Research.

Miller, Warren E., and J. Merrill Shanks. 1996. The New American Voter. Cambridge, MA: Harvard University Press. 
Nadeau, Richard, and Harold W. Stanley. 1997. “Age and Partisanship, 1952-1992.” In Southern Parties and Elections: Studies in Regional Political Change, ed. Robert P. Steed, Laurence W. Moreland, and Tod A. Baker. Tuscaloosa: University of Alabama Press.

Petrocik. 1987. "Realignment: New Party Coalitions and the Nationalization of the South." Journal of Politics 49: 347-375.

Pew Research Center. 2010. "Millennials: Confident. Connected. Open to Change." http:// www.pewsocialtrends.org/files/2010/10/millennials-confident-connected-open-tochange.pdf.

Pomper, Gerald M. 1989. “The Presidential Election.” In The Election of 1988, ed. Gerald M. Pomper. New York: Chatham House.

Pomper, Gerald M. 2001. “The Presidential Election.” In The Election of 2000, ed. Gerald M. Pomper. New York: Chatham House.

Pomper, Gerald M. 2010. "The Presidential Election: Change Comes to America." In The Elections of 2008, ed. Michael Nelson. Washington, DC: CQ Press.

Ray, Betty D. 2008. “The Gender Gap, The Marriage Gap, and Their Interaction.” Paper presented at the annual meeting of the Midwest Political Science Association, Chicago, April 3-5.

Schier, Steven E., and Janet M. Box-Steffensmeier. 2013. "The General Election Campaign.” In The American Elections of 2012, ed. Janet M. Box-Steffensmeier and Steven E. Schier. New York: Routledge.

Stanley, Harold W. 1988. "Southern Partisan Changes: Dealignment, Realignment or Both?" Journal of Politics 50: 65-88. 


\section{Endnotes}

${ }^{1}$ Because the 26th Amendment lowered the voting age to 18 in 1971, most of the members of this generation entered the electorate when they turned 18 , but the older members of the generation entered at a later age. Those born between 1946 and 1950 became eligible to vote when they turned 21, while those born after 1953 became eligible upon turning 18.

${ }^{2}$ The 2012 ANES survey overrepresents the Obama vote in the South. The ANES data have Obama winning 49.9 percent of the total vote and Romney winning 47.4 percent. The results calculated from the election returns are Obama receiving 45.0 percent and Romney 53.8 percent. However, the concern of this study is with the differences between generations, not with the actual vote percentages, so as long as the data are representative of generational differences, the inaccuracy in the actual vote percentages is unimportant.

${ }^{3}$ If we analyze all millennials, including nonvoters, we find that this generation does have a higher percentage of independents. However, independent millennials are less likely to vote, even more so than older independents, so among voters, there are relatively few millennial independents.

${ }^{4}$ The feeling thermometer used by the ANES surveys asks the respondent to place a person or a group on a scale from 0 to 100 degrees, where 0 degrees is very cold, 100 degree very warm, and 50 degrees neutral.

${ }^{5}$ The index of feelings toward blacks was formed from responses to three questions about blacks: (a) whether blacks should work their way up without any special favors, as other minorities did; (b) whether blacks face special conditions that make it difficult to work their way up; and (c) whether blacks have received less than they deserve. The index runs from 1 to 5 .

${ }^{6}$ Party identification was measured on a seven-point scale ranging from strongly Democratic to strongly Republican. Ideology also was measured on a seven-point scale ranging from very liberal to very conservative. There were a number of voters who did not place themselves on the seven-point ideology scale but who did classify themselves as liberal, moderate, or conservative with further prompting; these voters were classified as slightly liberal, moderate, and slightly conservative, respectively.

The index of social welfare issues combined responses to four questions: (a) whether government services and spending should be increased or decresed; (b) whether the federal government should see that everyone had a job and a good standard of living; (c) what level of government involvement in heath was desirable; and (d) whether or not the government should try to reduce economic inequality. All four components were measured on a scale from 1 to 7. The index is the mean score on the component items for respondents who had at least three valid responses.

An index of moral issues was formed from the following two components: (a) a question about when abortion should be allowed; and (b) an index of gay rights, formed from four separate questions. Both components were measured on a scale running from 1 to 4 , and the index is the mean score on the two component items.

${ }^{7}$ Seniors are the base generation for these dummy variables. A positive coefficient for any of the dummy variables for the generations would mean that generation is more Republican than seniors.

${ }^{8}$ Two measures of evaluations of Obama's performance were used in the analysis: approval of Obama's handling of the economy, and approval of his handling of foreign affairs. Each of these items are a four-point scale ranging from strongly approve to strongly disapprove. Candidate character traits were measured by an index that calculated the difference between Obama's mean score on six trait items and Romney's mean score on the same items. For details on this measure, see Holian and Prysby (2014).

${ }^{9}$ Exit poll results were taken from the CNN Web site (http://www.cnn.com/election/2014/ results/exit-polls).

${ }_{10}$ Mary Landreau in Louisiana, Kay Hagan in North Carolina, and Mark Warner in Virginia all were incumbents who ran for reelection in 2014. Mark Pryor in Arkansas also was on the ballot in both 2008 and 2014, but he was uncontested in 2008 , so it is not possible to compare the voting patterns in the two elections in this case. 